\title{
Skills Gap of Business Graduates in the Banking Sector of Bangladesh: Employers' Expectation Versus Reality
}

\author{
Faieza Chowdhury ${ }^{1}$ \\ ${ }^{1}$ Southeast Business School, Southeast University, Dhaka, Bangladesh \\ Correspondence: Faieza Chowdhury, Southeast Business School, Southeast University, Banani, Dhaka 1213, \\ Bangladesh. E-mail: faiezac30@gmail.com
}

Received: May 5, 2020

Accepted: September 3, $2020 \quad$ Online Published: November 23, 2020

doi:10.5539/ies.v13n12p48

URL: https://doi.org/10.5539/ies.v13n12p48

\begin{abstract}
Bangladesh is a fast growing economy and has managed to maintain an impressive annual average growth rate of above 6 percent over the last 10 years. Although there are almost 2 million young people who enter the job market every year, they often fail to meet the demands of the existing job market due to lack of adequate skills. Most of the graduates struggle to find a decent job as their skills fail to match the employers' expectations and needs. As the skill gap is brewing up creating a rise in unemployment, there is an urgent need for actions to enhance employability prospects of fresh graduates. In this study we aim to investigate the skill competence and skill gap of business graduates in the banking sector of Bangladesh. We utilized the mean scores of employability skills in terms of their significance as perceived by the employers in banks and the actual competency of business graduates. Findings of this study will allow students, employers, educators and policy makers in Bangladesh to recognize the critical areas where business graduates are lagging behind in the banking sector thus enabling them to take effective measures in order to reduce the skills gap.
\end{abstract}

Keywords: skills gap, training, learning, business graduates, higher education, banking sector, Bangladesh

\section{Introduction}

Bangladesh is going through a transformation process trying to build its pathway to becoming a middle income nation by 2021. Moreover, Government of Bangladesh (GOB) has also set their goals for Vision 2041, whereby they would like to transform Bangladesh into a developed country by 2041. Similarly, the United Nations has set Sustainable Development Goals (SDGs) globally to be achieved by 2030.

With more than half of the population in Bangladesh below the age of 25 years, the number of students graduating from universities has increased over the decade. In the year 2017, 3.2 million students were enrolled in tertiary level education and according to an estimate made by the University Grants Commission (UGC) of Bangladesh; this rate will reach to 4.6 million by the year 2026. Moreover, Dhaka which is the capital city of Bangladesh has the highest concentration of job seekers with 63000 to 67000 tertiary graduates annually (Choudhury, 2019).

According to a report titled 'Bangladesh Development Update October 2019: Tertiary Education and Job Skills' most of the graduates in Bangladesh struggle to find jobs, with more than one third of them remaining unemployed one to two years after graduation. This high rate of prolonged unemployment among the young graduates raises concern about the job readiness and relevance of skills at tertiary level in Bangladesh. Moreover for those who manage to get jobs, most of the employed graduates generally earn around Tk. 11,000 per month within one or two years after graduation (Alamgir, 2019). Furthermore, female graduates are far more likely to be unemployed compared to their male counterparts. It has been reported that 43 percent of the female graduates remain unemployed in comparison to 37 percent for the male graduates (The Daily Star, 2019). The rising cost of degree and growing oversight by the government are putting pressure on higher educational institutions to prove their value. The above statistics clearly prove that just having a degree or certificate in Bangladesh will not guarantee a job for the young graduates as they may lack the necessary skills required by the employers.

The modern competitive business world requires competency of workers both in blue collar and white collar job openings. However, most of the young graduates fail to secure a job as there is a clear mismatch between the expected skills required by employers and actual competencies of graduates in the job market. This situation gets worsen due to poor career counseling, lack of training institutes and unwillingness of graduates to learn new crafts 
and skills. Thus the unemployment problem in Bangladesh cannot be solved if the current education system is not revamped.

At present around 36 percent of employers in Bangladesh are facing shortages of skilled labor and this is leading to entry-level vacancies. Most employers want 'work-ready' graduates but the universities are only focusing on bookish knowledge ignoring the issues of skill development. Hence the existing curriculum of the universities should be linked to future careers of their graduates. Universities should help students develop their cognitive and soft skills to secure future jobs instead of only giving them knowledge on theories. Thus it is vital to build strong coordination between industries and universities to produce work-ready graduates with practical knowledge (Alamgir, 2019).

According to a study conducted by BIDS titled 'Labor Market and Skill Gap in Bangladesh' it is projected that the labor demand in Bangladesh will increase from 63.5 million in 2016 to 88.7 million in 2025. Moreover, it is also assumed that from the year 2021, the labor demand in Bangladesh will exceed the labor supply. Hence in Bangladesh only the 10 leading sectors alone will require 5.43 million trained labors in 2020 and 7.21 million in 2025 (Choudhury, 2019). Although labor demand is projected to increase but it is also mentioned that Bangladesh is going through major skills shortages in a study conducted by Asian Development Bank (ADB) in 2015. Additionally, a study by BIDS in 2016 also revealed that skill gap is highest in the agro-food sector followed by ready-made garments sector. Skill gap was also highest in IT and leather sectors for skilled workers (Khallol, 2017). The same study projected that demand for skilled workers will increase to 261 percent in agro-food sector, 54 percent in construction sector, 54.95 percent in healthcare sector, 35 percent in hospitality and tourism sector, 100 percent in IT sector, 107 percent in leather sector, 76.95 percent in engineering sector, 122.6 percent in RMG sector and 677 percent in shipbuilding sector during the fiscal years 2025-2026 (Abdin, 2017).

Therefore it is evident from the above findings that Bangladesh must develop the skills of its man power in every sector in order to achieve its Vision 2021 and 2041. At present the number of skilled workers and semi-skilled workers are lacking in almost every sectors in Bangladesh. To overcome this skills gap, the Government of Bangladesh must take vital initiatives and one such step is to restructure the current education system in Bangladesh.

The quality of education provided by academic institutions can have direct implications to employability of graduates as universities are responsible to ensure that their students meet the current demands of the labor market and create workforce accordingly. One major problem is the fact that most academic institutions currently offer courses based on outdated curriculums and teaching technologies. Hence in most cases graduates lack the knowledge and skills necessary to secure jobs in today's competitive and dynamic industries. Lack of skill development is a colossal problem which can create hindrances for achieving sustainable growth in Bangladesh. Most of the current graduates are failing to meet the current market needs of the industries. At present Bangladesh is earning around $\$ 5$ billion by exporting more than 8 million semi-skilled or unskilled workers to Middle East and various other South Asian countries. However, Bangladesh is also lagging behind in terms of people with mid-level managerial and technical skills hence Bangladesh is paying huge amount of money for recruiting these foreign professionals. Due to the skill gap in Bangladesh, countries such as India remitted \$10 billion in 2017 from Bangladesh (Naim, 2018). This is a clear indication that at present the country is lagging behind in terms of creating mid-level and technical workforce for the corporate houses. There is a shortage of skilled labor force such as project and product managers, system analyst, software engineers and quality assurance specialists (Choudhury, 2019).

In response to the present situation, Government of Bangladesh has instructed all higher academic institutions to put priority on technical and vocational education. Universities are expected to produce graduates prepared for success in the workforce which matches the perception of the employers. However, students graduating from the universities often remain unemployed as they fail to meet the required skills which are demanded by the employers in various industries. As per the graduate tracking survey, 30 percent of the college graduates and 20 percent of university graduates experience joblessness lasting more than a year (Alamgir, 2019). Nevertheless, a major challenge for universities to improve the skills of their current graduates is identifying the specific set of skills that employers demand from these graduates.

As a developing country, Bangladesh needs a thriving banking industry to foster economic growth. Over the last three decades, the country has experienced a major expansion of its banking industry. After the country gained its independence in 1971, the banking industry in Bangladesh consisted of 6 nationalized commercial banks and 9 foreign banks. At presents, the banks in Bangladesh can be classified into two broad types: scheduled banks and non-scheduled banks. There are 59 scheduled banks in Bangladesh which operates under the full control and 
supervision of the Bangladesh Bank under the Bangladesh Bank Order, 1972. On other hand, there are 5 non-scheduled banks which are established for special objectives and do not perform all the functions of the scheduled banks. Some of the non-scheduled banks in Bangladesh are Ansar VDP Unnayan Bank, Grameen Bank, Jubilee Bank and Palli Sanchay Bank. Currently in Bangladesh there are eight Islamic banks while some of the Non-Islamic banks also offer Islamic banking services alongside their normal operations. Moreover Bangladesh operates the world's biggest Islamic microfinance scheme.

However, similar to other industries in the country, employers in banks are facing difficulties in finding graduates that meet their expectations and needs. On the other hand, most of the young graduates are struggling to find a decent job in banks due to lack of appropriate skills. Apart from technical knowledge, much emphasis is placed by employers in banks on developing soft skills of workers such as communication and social skills. Employers in banks would like to hire graduates with skill competencies on English, ICT and higher-order thinking such as problem solving, communication and teamwork. Moreover, technological advancements have made the skills requirement unpredictable, as a result of which workers today need to be more adaptive to the dynamic banking sector. According to the world economic forum, at least 133 million new job roles will be generated by the year 2022 and there will be strong demand for skills which computer cannot easily master such as creative thinking and problem solving (Chakraborti, 2019).

This research aims to pinpoint the key skills and attributes which are required by bank employers from the business graduates in Bangladesh. We try to identify what type of skills the employers in the banking sector of Bangladesh expects from the business graduates and in which specific areas the young graduates are lagging behind. Hence, this study has four main objectives: (1) To identify the skills that employers in banks demand from current business graduates (2) To assess employers' perception about the level of skills competencies held by current business graduates (3) To analyze the current skills gap by comparing employers' expectations against the actual skill competencies of business graduates (4) Finally, to provide suggestions on what type of initiatives can be taken by respective authorities to overcome the skills gap in the banking sector of Bangladesh.

\section{Literature Review}

A definition of employability is provided by the University of Exeter "the establishment of certain mechanisms by which students can develop their abilities to use and deploy several skills to enhance their own academic learning to become more employable in the future". According to Yorke and Knight (2004), employability is the mixture of achievements, skills, understandings and some personal attributes that enable graduates to gain employment. Glover et al., (2002) state that employability skill refers to the ability of workers to arrange tasks, set goals, participate in change management process, network, continuously learn and work within the team.

Dupre and Williams (2011) state that employability can be divided into two distinct categories: external employability and internal employability. External employability refers to the ability and willingness of workers to switch from one company to another. On the other hand, internal employability refers to workers' ability or willingness to continue working within an existing company. Moreover, employability skills can be categorized into two key types: hard skills and soft skills. Hard skills are subject-specific knowledge such as mathematical skills to solve problems and computer skills to analyze data. On the other hand, soft skills are a combination of people skills, social skills, and communication, character and personality traits. Soft skills enable people to work well with others, navigate within their work environment and perform well to achieve goals with complementary hard skills. Furthermore, soft skills are those qualities which are often described by employers as those characteristics of a person that do not depend on acquired subject knowledge. According to Robinson and Garton (2008), soft skills are more important than hard skills as they ensure employability. Moreover, it is often difficult to teach soft skills in the class in an equivalent way as the hard skills can be.

Weligamage (2009) found in the study that employers' expectations of employability skills can vary according to the types of country, economic condition, business sector and business size. Dearing (2016) points out that employability skills may vary with region, size and types of business market orientations. According to Hillage and Pollard (1998), there are four processes for effective employability. Firstly, one must gain appropriate knowledge and skills; secondly, these skills need to be applied in real life scenarios; thirdly, a person must present his/her skills to potential employers to boost employability chances and finally one must acquire the necessary skills required to secure a job such as CV writing, interview techniques etc. Coopers and Lybrand in 1998 claimed that employability skills have four key parts: 1) traditional and instrumental abilities, 2) key skills, 3) personal qualities and 4) extensive knowledge of organization. Furthermore, Juhdi et al. (2010) pointed out that employability skills are a set of managing resources, interpersonal skills, teamwork, communication and problem solving skills. 
Employability of graduates is a key performance indicator to assure the quality of a university's program. Graduates can develop their skills through various activities such as internships, part-time jobs, summer jobs or even weakened jobs. Generally in the banking sector, most jobs require workers to carry out all necessary monthly transactions while dealing with clients and colleagues from different sectors for an overall success in current dynamic work environment (Abbasi et al., 2018). Those seeking for jobs in the banking sector require certain vital skills such as numeric, analytical and computing skills (Osmani el al., 2015).

It is apparent that today most of the managers are looking for graduates who are 'work-ready'. Hence understanding the skills and attributes that are expected from graduates in the banking sector will enable fresh graduates to respond properly towards the employers expectations and meet their needs. Some of the fundamental skills in the banking sector include oral, writing and communication abilities, ability to analyze and interpret numbers, statistical knowledge, critical thinking and competency in computer technology. Mc Cabe (2010) states that a graduate's job is not assured unless they prove that the soft skills and personal attributes that they have can be successfully implemented in performing various tasks. Companies want to hire graduates who can use their abilities and skills to perform various tasks, quickly gets familiarize with the workplace culture and gradually evolve as a leader within the organization.

Bangladesh is now at the crossroads to be transformed into a high productive growth economy with aims to become a middle income nation and later a developed nation under Vision 2021 and Vision 2041. For this purpose the Government of Bangladesh has taken critical steps to strengthen the skill development ecosystem and formed NSDA in 2018 by enacting the National Skills Development Authority Act. The NSDA is working effectively to transform and regulate the skill development system in Bangladesh ("Reducing skill gap", 2019). As the country is now facing shortages of skilled manpower, higher education institutions in Bangladesh should design their curriculum based on the current market needs. It is vital that all the universities build a strong rapport with different industries and devise a framework to identify skills gaps and formulate strategies for skill development of their students.

\section{Conceptual Framework}

There have been endless debates in literature regarding which employability skills are more preferable by employers. Some of the most commonly used employability skills used in previous studies are teamwork, information technology (IT), creatively, communications, interpersonal skills, leadership, self-management and critical thinking (Osmani et al., 2015; Harris \& King, 2015). According to Finch et al. (2013) adaptability is an important skill for graduates. Adaptability refers to workers ability to be flexible and quickly response to any new situations, demands and conditions. Communication skills are vital as it enable workers to work effectively with others (Jackson, 2014). Interpersonal skills refer to the ability to communicate effectively with others and build good work relationships. Leading is a vital skill as employers often want to hire workers who can lead and coach others in the workplace (Finch et al., 2013). Finally, people management skills are desirable for team collaboration, maintaining solid relationships with colleagues, appreciation of others inputs and feedback. In this study we have included six skill parameters of graduate employability in the banking sector of Bangladesh: 1) workplace literacy and numeric skills, 2) technical skills, 3) office etiquettes, 4) leadership skills, 5) communication and negotiation skills and 6) problem solving skills (Figure 1). 


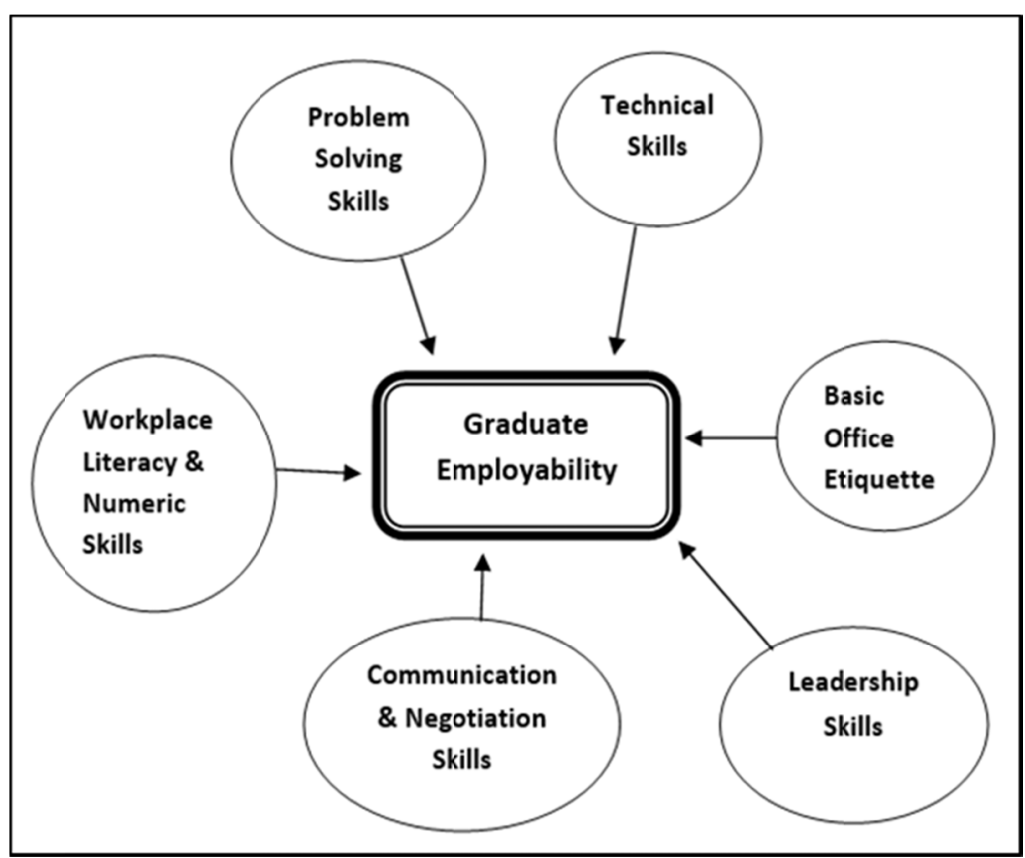

Figure 1. Skill parameters of graduate employability in the banking sector of Bangladesh

\section{Methodology}

The methodology section is divided into four sub-sections: target group, sampling technique, data collection and analytical technique.

\subsection{Target Group}

The survey was conducted on ten banks and the questionnaire has been distributed to 50 employees of banks holding various positions such as supervisors, assistant managers, deputy managers, department managers and HR managers. Those who are in the top management positions such as CEOs and CFOs were excluded from the target sample as they do not directly deal with entry-level graduates.

\subsection{Sampling Technique}

The selection of the participants for the study was based on convenience sampling technique. Researcher preferred this method as the participants and banks used in the survey were selected based on three main criteria: familiarity, availability and accessibility.

\subsection{Data Collection}

Primary data was collected by conducting a survey utilizing a structured questionnaire as an instrument with 22 close-ended questions. All participants in this study were employers of selected banks in Bangladesh who were requested to fill out a questionnaire and to evaluate the skills competencies of business graduates working in their banks for the last three years. Furthermore, respondents were asked for limited personal information, followed by demographic questions such as their current designation in the bank, gender, recent academic degrees and number of years of work experience.

\subsection{Analytical Technique}

This study took the efforts to explore the skills set which are expected from business graduates by employers in the banking sector of Bangladesh. Moreover, we also constructed a skill gap index, where we identified the specific skills that the current business graduates are lagging behind by comparing employer's expected skill score against the actual skill score of these graduates. Firstly, we developed a structured questionnaire and collected data on a psychometric scale called Likert Scale. Employers in banks were asked to provide their responses on six skill parameters of graduate employability in banks: 1) workplace literacy and numeric skills, 2) technical skills, 3) office etiquettes, 4) leadership skills, 5) communication and negotiation skills and 6) problem solving skills (Figure 1: Conceptual Framework). Each parameter covered various aspects of skills set and for each skill set, a mean score was calculated using five responses which were strongly agree (SA), agree (A), neutral $(\mathrm{N})$, disagree (DA) and strongly disagree (SDA). Thus, at first using the Likert Scale we calculated the mean scores of students' 
expected skill competency and the mean scores of students' actual skill competency. The difference between the actual mean scores and the expected mean scores for each skill set is used to identify the skills gap for each specific skill set.

As mentioned earlier, in this study we aim to identify the skills gap of current business graduates in the banking sector of Bangladesh. Hence by comparing the mean scores of students' expected skills against their actual skills, we constructed a skill gap index. The data has been analyzed using STATA statistical software. Descriptive statistical techniques was applied to analyze the data and mean scores was the main criteria to measure the level of skills gap for each employability skills of the current business graduates in the banking sector of Bangladesh.

\section{Findings and Discussion}

As mentioned earlier, the questionnaire has been distributed to employers of some selected banks in Bangladesh. Hence the first part of the questionnaire includes demographic questions about the 50 respondents regarding their designation at these banks, recent academic degrees and number of years of work experiences in the banking sector of Bangladesh.

In Table 1, it can be observed that among the 50 participants in this study, half of the participants are supervisors, 16 percent are HR managers and those holding positions of deputy manager and assistant manager are 14 percent and 20 percent respectively. Additionally, the numbers of male participants are higher compared to their female counterparts. The dominant participants are 76 percent males in comparison to 24 percent females. This is an indication that women occupying higher positions in the banking sector of Bangladesh are still lower compared to men.

Furthermore, 82 percent of the respondents are Master degree holders and 16 percent holds Bachelor degree. Only one participant holds a professional degree and none of the participants have diploma or $\mathrm{PhD}$. Moreover, it can be seen that 64 percent of the respondents have less than 5 years of work experience in banks and 36 percent of the respondents have spent 5 to 10 years of his or her life working in banks. However, none of the participants in this study have more than 10 years of work experience in the banking sector. This finding is not surprising as in this study we have deliberately excluded people in the top management positions as in most cases these people do not directly deal with entry-level graduates working in banks.

Table 1. Participants' demographic data

\begin{tabular}{lccc}
\hline & & Frequency & Percent \\
\hline \multirow{3}{*}{ 1. Gender } & Male & 38 & 76 \\
& Female & 12 & 24 \\
\hline \multirow{3}{*}{ 2. Current Designation } & HR managers & 8 & 16 \\
& Deputy managers & 7 & 14 \\
& Assistant managers & 10 & 20 \\
& Supervisors & 25 & 50 \\
\hline \multirow{4}{*}{ 3. Academic Qualification } & Diploma & 0 & 0 \\
& Bachelor & 9 & 16 \\
& Master & 40 & 82 \\
& PhD & 0 & 0 \\
& Professional degree & 1 & 2 \\
\hline \multirow{3}{*}{ 4. Years of Experience } & Less than 5 years & 32 & 64 \\
& 5 to 10 years & 18 & 36 \\
& 11 to 20 years & 0 & 0 \\
& More than 20 years & 0 & 0 \\
\hline
\end{tabular}

Survey: 2019.

As it is depicted in Table 2, the respondents in this study who are mainly employers of some selected banks in Bangladesh, consider oral communication, punctuality and maintaining good relations with colleagues as the most important employability skills with expected mean ratings of 4.70. The second important component of employability is 'maintaining positive attitude in the workplace' with expected mean rating of 4.60. The third significant set of employability skills with expected mean scores of 4.50 are 'use of mathematical knowledge, ability to apply computer knowledge, decision making ability and solve problems in group settings'. On the other 
hand, after assessing the actual competencies of young graduates in the banking sector of Bangladesh, it can be seen that most of the respondents in the survey reflected that at present the young graduates working in their banks are able to apply computer knowledge in the workplace settings however in certain areas they are lagging behind mainly, 'written communication, negotiating effectively with clients, identify and anticipate problems, solve problems in group settings and find quick solutions to problems'.

Finally, after analyzing the gaps in various skill elements, results indicate that the skill gap size was above 1.00 for thirteen skills: oral communication, written communication, use of mathematical knowledge, punctuality and formal attire, good relations with colleagues, maintain positive attitude in the workplace, decision making ability, formulate and implement strategies, initiate action for improvements, negotiate effectively, identify and anticipate problems, find quick solutions to problems and solve problems in group settings. While the skill gap was highest for the skill element 'solve problems in group setting', it was lowest for the skill element 'ability to apply computer knowledge' with mean skill gap ratings of 2.00 and 0.60 , respectively.

Table 2. Mean scores of expected skills competency, actual skills competency and skills gap

\begin{tabular}{|c|c|c|c|}
\hline Employability Skills & $\begin{array}{c}\text { Expected } \\
\text { Mean }\end{array}$ & $\begin{array}{l}\text { Actual } \\
\text { Mean }\end{array}$ & Skill Gap Mean \\
\hline \multicolumn{4}{|l|}{ A. Workplace Literacy and Numeric Skills } \\
\hline Oral Communication & 4.70 & 3.00 & 1.70 \\
\hline Witten Communication & 4.30 & 2.90 & 1.40 \\
\hline \multirow[t]{2}{*}{ Use of mathematical knowledge } & 4.50 & 3.10 & 1.40 \\
\hline & 4.50 & 3.00 & 1.50 \\
\hline \multicolumn{4}{|l|}{ B. Technical Skills } \\
\hline Ability to use office equipment & 4.40 & 3.40 & 1.00 \\
\hline Ability to apply computer knowledge & 4.40 & 3.80 & 0.60 \\
\hline \multirow[t]{2}{*}{ Use of latest software } & 4.20 & 3.20 & 1.00 \\
\hline & 4.33 & 3.47 & 0.86 \\
\hline \multicolumn{4}{|l|}{ C. Basic Office Etiquettes } \\
\hline Punctuality and formal attire & 4.70 & 3.40 & 1.30 \\
\hline Good relations with colleagues & 4.70 & 3.10 & 1.60 \\
\hline \multirow[t]{2}{*}{ Maintain positive attitude in workplace } & 4.60 & 3.30 & 1.30 \\
\hline & 4.66 & 3.27 & 1.39 \\
\hline \multicolumn{4}{|l|}{ D. Leadership Skills } \\
\hline Decision making ability & 4.50 & 3.20 & 1.30 \\
\hline Formulate and implement strategies & 4.40 & 3.30 & 1.10 \\
\hline \multirow[t]{2}{*}{ Initiate action for improvements } & 4.40 & 3.10 & 1.30 \\
\hline & 4.43 & 3.20 & 1.23 \\
\hline \multicolumn{4}{|l|}{ E. Communication and Negotiation Skills } \\
\hline Negotiate effectively & 4.20 & 2.80 & 1.40 \\
\hline Communicate effectively with diverse people & 4.10 & 3.10 & 1.00 \\
\hline \multirow[t]{2}{*}{ Coaching and mentoring ability } & 4.00 & 3.20 & 0.80 \\
\hline & 4.10 & 3.03 & 1.07 \\
\hline \multicolumn{4}{|l|}{ F. Problem Solving Skills } \\
\hline Identify and anticipate problems & 4.20 & 2.90 & 1.30 \\
\hline Find quick solutions to problems & 4.40 & 2.80 & 1.60 \\
\hline \multirow[t]{2}{*}{ Solve problems in group settings } & 4.50 & 2.50 & 2.00 \\
\hline & 4.37 & 2.73 & 1.64 \\
\hline
\end{tabular}

Survey: 2019.

\section{Recommendation}

Due to inevitable factors such as climate change, urbanization and global shifts of economic power, most of the markets in the world are continuously evolving. Moreover, rapid technological advancements are making some traditional forms of jobs obsolete while creating demands for new high skilled jobs. According to the report published by World Economic Forum (WEF) in 2018, technological advancements will eventually displace a wide 
range of traditional stable jobs because in the future some of these jobs will be performed by machines. Moreover, every year almost 2.2 million young people enter the job market but a majority of them remain unemployed or get engaged in low income jobs at home or abroad due to lack of skills. At present Bangladesh is facing shortages in supply of skilled and semi-skilled workers and this situation could worsen in the coming years if proper initiatives are not taken by appropriate authorities (Bangladesh Post, 2019).

The labor market survey in 2017 demonstrated that most of the employers in Bangladesh, struggle to fill job vacancies for highly skilled positions such as technicians, project managers, analysts etc. It was also highlighted that three higher order soft skills which are most relevant for current work environment are positive personality, work attitude and problem solving. Hence employers in Bangladesh are seeking graduates with higher order cognitive and soft skills but in reality they struggle to find such graduates. Almost half the population of Bangladesh is below 25 years of age and these young people must be given proper education and training to develop their soft skills which will ensure their future job prospects (Alamgir, 2019).

At present the current BBA program offered by the universities in Bangladesh require the students to attend a 4 year course study including a 3/4 months internship practice. However, this structure gives very little scope to students for enhancing their soft skills through gaining practical work experiences. Hence universities in Bangladesh need to re-structure and re-design these programs and make them more work-oriented and practical experience based for their students.

It is vital for all academic institutions to teach their students those specific skills which are currently in high demand by offering them work-oriented courses. These work-oriented courses should be offered to students keeping in mind the specific industries' need-based demands. At present the courses which are taught in most of the universities are concentrated on theories with very little knowledge provided to students on how to apply these theories in real life scenarios. Hence it is imperative for the universities to re-design their curriculum and introduce work integrated learning (WIL), where students can learn the skills and gain the practical experience required in the job market (Chowdhury, 2020). Moreover, in most of the renowned universities around the world, executive education is offered to students which are not provided by the current academic institutions in Bangladesh.

To help graduates succeed in their future career, a mix of both hard skills and soft sills will be required while understanding the labor demands for the specific region in which the graduates will be seeking employment to fill the skill gap. The higher education institutions in Bangladesh need to help solve the country's skills gap and boost economic growth (The Financial Express, 2017). Moreover, to tackle the issue of skill gap in Bangladesh, both public and private universities must create a mechanism in order to identify what type of skill elements are currently demanded by employers in various industries (The Daily Star, 2017). There needs to be a match between employers' expectations and graduates' qualifications. Universities can create strong links with industry experts and potential employers to create a skill-set matrix. This skill-set matrix will provide information to graduates about what type of skill-set they need to fulfill for securing job positions within a specific industry. The skill-set matrix will enable the employers to convey their expectations to universities and students so that they can take effective measures for future job recruitments. Universities can also benefit from this kind of skill-set matrix as they will be able to update their current curriculum to meet the requirements of the current job market. Moreover, universities need to establish centralized and coordinated mechanisms to assess the skills set of their current graduates. Graduates are assessed by the potential employers based on education, skills set and individual mindset. Hence it is important for universities to improve the skills of their graduates and build positive mindset of their students while imparting them theoretical knowledge from books.

Finally, it is not possible for the government alone to create millions of job thus it requires long term commitment of a wide cross-section of society including public and private institutions as well as development partners (International Labor Organization [ILO], 2019). Training institutions in Bangladesh need to play a pivotal role in producing work-ready graduates and it is imperative that they participate in the skill development process to reduce unemployment and foster growth. It is important for employers to set standards which are more realistic and the labor force skills should be enhanced according to these standards. In order to reduce the skills gap, higher education institutions must integrate their academic curriculum with practical work oriented experiences. Universities need to take approaches where students can develop their practical skills and transferable skills. Universities also need to give students more opportunities to apply their multi-disciplinary knowledge into practices at real workplace settings.

\section{Conclusion}

Bangladesh has experienced a continuous growth in GDP over the last 10 years and this growth journey is projected to continue in the coming decades. However a critical factor which the country must ensure to maintain 
sustainable growth in the future is availability of skilled labor force. Skill development of the current population is the only way for the country to achieve sustainable economic growth.

In this research we found that business programs in Bangladesh should give more attention to ensure that their business graduates obtain certain skills which are given high importance by employers in the banking sector. The three key skill-set which has obtained the highest skill gap in our study are firstly, "problem solving skills" with a mean total skill gap score of 1.64, secondly, "workplace literacy and numeric skills" with mean skill gap score of 1.50 and thirdly, "basic office etiquettes" with average skill gap rating of 1.39. The results of this study will have many implications as it will allow policy makers and decision makers at higher academic institutions to design their business programs in a way which meets the current requirements of the job market in the banking sector of Bangladesh.

Finally, similar to any other study this paper does have some limitations. The sample size was restricted to 50 participants due to inaccessibility and poor response rates of the employees in the banking sector of Bangladesh. It is recommended that further research should be conducted with larger sample size and applying mixed-method approaches by utilizing both semi-structured interviews and survey techniques.

\section{References}

Abbasi, F. K., Ali, A., \& Bibi, N. (2018). Analysis of Skill Gap for Business graduates: Managerial perspective from Banking Industry. Education + Training, 60(4), 354-367. https://doi.org/10.1108/ET-08-2017-0120

Abdin, J. (2017). Skill development a priority for Sustainable Development. Retrieved from https://ssrn.com/abstract=308950

Alamgir, S. (2019). 36\% employers in Bangladesh face skilled man power shortage. Dhaka Tribune. Retrieved from https://www.dhakatribune.com

Bangladesh Post. (2019). Reducing skills gap to boost growth stressed. Retrieved from https://bangladeshpost.net

Chakraborti, A. (2019). Skills development to shape future workforce. The Daily Star. Retrieved from https://www.thedailystar.net

Choudhury, F. (2019). Skills gap in the IT sector: Utilizing the power of Youth. Retrieved from https://www.lightcastlebd.com

Chowdhury, F. (2020). Work Integrated Learning at Tertiary Level to Enhance Graduate Employability in Bangladesh. International Journal of Higher Education, 9(4), 61-68. https://doi.org/10.5430/ijhe.v9n4p61

Dearing, R. (2016). The Dearing Report (1997).

Dupre, C., \& Williams, K. (2011). Undergraduates' Perceptions of Employer Expectations. Journal of Career and Technical Education, 26(1), 8-19. https://doi.org/10.21061/jcte.v26i1.490

Finch, D. J., Hamilton, L. K., Baldwin, R., \& Zehner, M. (2013). An exploratory study of factors affecting $\begin{array}{llll}\text { undergraduate employability. Education }+ & \text { Training, 55(7), }\end{array}$ https://doi.org/10.1108/ET-07-2012-0077

Glover, D., Law, S., \& Youngman, A. (2002). Graduateness and Employability: Student Perceptions of the Personal Outcomes of University Education. Journal of Post Compulsory Education, 7(3), 293-306. https://doi.org/10.1080/13596740200200132

Harris, C. R., \& King, S. B. (2015). Rural Mississippi Community College students' perceptions of employability skills. Community College Journal of Research and Practice, 39(4), 383-386. https://doi.org/10.1080/10668926.2014.981888

Hillage, J., \& Pollard, E. (1998). Employability: Developing a Framework for Policy Analysis.

International Labor Organization. (2019). ILO and partners pledge to develop 21st century skills for Bangladesh. Retrieved from https://www.ilo.org

Jackson, D. (2014). Testing a model of undergraduate competence in employability skills and its implications for $\begin{array}{llll}\text { stakeholders. Journal of Education and Work, 27(2), 220-242. } & \text {. }\end{array}$ https://doi.org/10.1080/13639080.2012.718750

Juhdi, N., Pa-Wan, F., Othman, N., \& Moksin, H. (2010). Factors Influencing Internal and External Employability of Employees. Business and Economics Journal, 1, 1-10.

Khallol, A. S. (2017). Almost 90\% of Bangladesh's workers are unskilled. Dhaka Tribune. Retrieved from https://www.dhakatribune.com 
McCabe, G. (2010). Graduate attributes and Employability: Helping universities and students prepare for the Changing Landscape (1st ed.). Edinburgh: TLA Centre.

Naim, K. (2018). Bangladesh's struggle to resolve the skill gap. ICE Business Times. Retrieved from https://ibtbd.net

Osmani, M., Weerakkody, V., Hindi, N. M., Al-Esmail, R., Eldabi, T., Kapoor, K., \& Irani, Z. (2015). Identifying the trends and impact of graduate attributes on employability: A literature review. Tertiary Education and Management, 21(4), 367-379. https://doi.org/10.1080/13583883.2015.1114139

Robinson, S. J., \& Garton, B. (2008). An Assessment of the Employability Skills Needed by Graduates in the College of Agriculture, Food and Natural Resources at the University of Missouri. Journal of Agricultural Education, 49(4), 96-105. https://doi.org/10.5032/jae.2008.04096

The Daily Star. (2017, July 24). Skills dearth to dent development: Study. Retrieved from https://www.thedailystar.net

The Daily Star. (2019). One in three graduates unemployed. Retrieved from https://www.thedailystar.net

The Financial Express. (2017). Capacity building essential to meet skill gap: Study Report. Retrieved from https://thefinancialexpress.com.bd

Weligamage, S. (2009). Graduates' Employability Skills: Evidence from Literature Review (pp. 115-116). ASAIHL. Colombo: University of Kelaniya.

Yorke, M., \& Knight, P. (2004). Embedding Employability into the Curriculum. New York: The Higher Education Academy.

\section{Copyrights}

Copyright for this article is retained by the author(s), with first publication rights granted to the journal.

This is an open-access article distributed under the terms and conditions of the Creative Commons Attribution license (http://creativecommons.org/licenses/by/4.0/). 